Emil Bartosz Rozenek ${ }^{1}$,Karolina Wilczyńska², Monika Górska³, Napoleon Waszkiewicz²

\title{
DESIGNER DRUGS - STILL A THREAT?
}

\section{NARKOTYKI PROJEKTOWANE (DOPALACZE) - CZY NADAL SĄ ZAGROŻENIEM?}

\author{
${ }^{1}$ Medical University of Bialystok, Students' Scientific Circle at the Department of Psychiatry \\ ${ }^{2}$ Medical University of Bialystok, Department of Psychiatry \\ ${ }^{3}$ Medical University of Lodz, Department of Clinical Pharmacology \\ ${ }^{1}$ Uniwersytet Medyczny w Białymstoku, Studenckie Koło Naukowe przy Klinice Psychiatrii \\ ${ }^{2}$ Uniwersytet Medyczny w Białymstoku, Klinika Psychiatrii \\ ${ }^{3}$ Uniwersytet Medyczny w Łodzi, Zakład Farmakologii Klinicznej
}

\begin{abstract}
INTRODUCTION. In Poland, an increasing number of psychoactive substances are becoming prohibited by law as psychotropic or narcotic substances, or as new psychoactive substances (NPSs). Owing to the enormous technological possibilities offered by today's science, synthesis of new derivatives of prohibited compounds is no longer a problem. The moment a dangerous substance is outlawed, new designer drugs (in Poland known as 'dopalacze') appear on the market.

STATE OF KNOWLEDGE. An amendment to the Act on Counteracting Drug Addiction issued in July 2018 made it possible for the NPS to be considered drugs by law. Synthetic cannabinoids and cathinone derivatives make up the majority of NPSs identified by the authorities in Poland. Synthetic cannabinoids which can, unlike cannabinoid receptor agonists of plant origin, cause death by somatic toxicity, are particularly dangerous. The ability to quickly recognize poisoning with synthetic opioids is crucial, since an antidote reversing the depressive effect of opioids on the respiratory center can be administered.

SUMMARY. This work collects the most important and up-to-date information on designer drugs, based on reports and articles published between 2015 and 2019. The covered aspects include: the current definition of designer drugs in relation to the Polish law, their exact division due to the clinical effects they cause and the description of the threats they pose. Emphasis was given to the current situation of the designer drug market in Poland.
\end{abstract}

Keywords: designer drugs, street drugs, drug design, hallucinogens, cannabinoids, opioids, benzodiazepines

\section{STRESZCZENIE}

WSTĘP. W Polsce coraz większa liczba substancji psychoaktywnych staje się zakazanymi ustawowo substancjami psychotropowymi lub odurzającymi lub nowymi substancjami psychoaktywnymi (NSP). Ze względu na ogromne możliwości technologiczne, jakie zapewnia dzisiejszy świat nauki, synteza nowych pochodnych zakazanych związków nie stanowi problemu. $Z$ momentem zdelegalizowania niebezpiecznych substancji, na rynku niemal od razu pojawiają się nowe, projektowane narkotyki (od ang. designer drugs), w Polsce potocznie zwane "dopalaczami".

STAN WIEDZY. W lipcu 2018 roku wydano nowelizację ustawy o przeciwdziałaniu narkomanii, umożliwiającą traktowanie z mocy prawa nowych substancji psychoaktywnych na równi z narkotykami. Pochodne katynonu i syntetyczne kannabinoidy stanowią większość NSP identyfikowanych przez odpowiednie organy w Polsce. Szczególnie groźne okazują się być syntetyczne kannabinoidy, mogące, w przeciwieństwie do agonistów receptorów kannabinoidowych pochodzenia roślinnego, powodować zgony z powodu toksyczności somatycznej. Umiejętność szybkiego rozpoznania zatrucia syntetycznym opioidem jest szczególnie istotna, ze względu na możliwość podania odtrutki odwracającej depresyjne działanie opioidów na ośrodek oddechowy. 
PODSUMOWANIE. Niniejsza praca stanowi zbiór najważniejszych i aktualnych informacji na temat dopalaczy w oparciu o raporty i artykuły naukowe opublikowane w latach 2015-2019. Artykuł zawiera między innymi: przedstawienie aktualnej definicji dopalaczy w odniesieniu do aktów prawnych obowiązujących w Polsce, dokładny podział dopalaczy ze względu na efekty kliniczne, jakie wywołują oraz opis zagrożeń, jakie ze sobą niosą. Szczególna uwaga została poświęcona sytuacji epidemiologicznej związanej z zażywaniem dopalaczy na terenie Polski.

Słowa kluczowe: narkotyki projektowane, narkotyki uliczne, tworzenie leków, halucynogeny, kannabinoidy, opioidy, benzodiazepiny

\section{INTRODUCTION}

'Designing' drugs, i.e. modifying the initial compound to circumvent legal regulations, often makes it difficult or impossible to identify the compound in toxicological studies and increases its psychotropic activity (1).

Even at low doses most designer drugs strongly impact the CNS, hence the high risk of overdosing, poisoning and even death. Difficulties in toxicological identification of NPSs, presence of impurities and lack of an effective antidote (which can only be administered in case of synthetic benzodiazepines - flumazenil, opioids - naloxone, or anticholinergic substances - physostigmine) all deteriorate treatment efficacy (2). One of the most common complications of designer drug poisoning is acute rhabdomyolysis. The products of muscle breakdown, especially in a rapidly progressing and intense rhabdomyolysis, may cause acute kidney injury (3). The treatment of designer drug poisoning (unless it is possible to administer an antidote) is focused on the management of the psychological and somatic symptoms (4).

The aim of our review is to provide a condensed, yet exhaustive overview of what designer drugs are today and the consequences following their use, with emphasis on the problem of designer drugs in Poland.

\section{MATERIAL AND METHOD}

The article was based on the key publications presenting the current state of knowledge on designer drugs (as of 01.08.2019), found in the MEDLINE database, reports from the Main Sanitary Inspectorate (pol. Główny Inspektorat Sanitarny - GIS) website as well as other Polish institutions such as the Information Center on Drugs and Drug Addiction (CiNN), Public Opinion Research Center (CBOS), National Bureau for Drug Prevention (KBPN) and School of Social Psychology (SWPS). We searched for the following keywords: 'designer drugs', 'party pills', 'street drugs', 'research chemicals', 'new psychoactive substances'. The unsystematic review covered literature published in 2015-2019, written in Polish or English. The

\section{WPROWADZENIE}

„Projektowanie” narkotyków, czyli modyfikowanie wyjściowego związku w celu ominięcia regulacji prawnych, często utrudnia bądź uniemożliwia identyfikację związku w badaniach toksykologicznych, a także powoduje nasilenie działania psychotropowego (1).

Większość dopalaczy już w niewielkich dawkach wywiera silny wpływ na ośrodkowy układ nerwowy (OUN), stąd wysokie ryzyko przedawkowania, zatrucia, a nawet zgonu. Trudność w identyfikacji NSP badaniem toksykologicznym, obecność zanieczyszczeń i brak skutecznego antidotum (substancję odwracającą działanie można zastosować jedynie w przypadkach zatruć syntetycznymi beznzodiazepinami - flumazenil, opioidami - nalokson, czy też substancjami antycholinergicznymi - fizostygmina) wpływają na obniżenie skuteczności leczenia (2). Jednym z najczęstszych powikłań zatruć dopalaczami jest ostra rabdomioliza. Produkty rozpadu mięśni, szczególnie przy szybko przebiegającym i nasilonym procesie rabdomiolizy, mogą skutkować ostrą niewydolnością nerek (3). Leczenie zatrucia dopalaczami (poza wyjątkami możliwość podawania odtrutek) zazwyczaj skupia się zatem na postępowaniu mającym na celu opanowanie psychicznych i somatycznych objawów zatrucia (4).

Celem pracy jest przedstawienie w skondensowanej, ale i wyczerpującej formie tego, czym są dziś dopalacze oraz jakie konsekwencje może nieść ze sobą ich zażywanie, ze szczególnym uwzględnieniem problemu dopalaczy w Polsce.

\section{MATERIAŁ I METODY}

Artykuł powstał w oparciu o najważniejsze publikacje prezentujące aktualny stan wiedzy na temat narkotyków projektowanych (stan na 01.08.2019) zamieszczone $\mathrm{w}$ bazie MEDLINE, doniesienia zawarte na stronach Głównego Inspektoratu Sanitarnego (GIS), a także raporty z innych polskich instytucji, jak: Centrum Informacji o Narkotykach i Narkomanii (CiNN); Centrum Badania Opinii Społecznej (CBOS); Krajowego Biura ds. Przeciwdziałania Narkomanii (KBPN) i Szkoły Wyższej Psychologii Społecznej 
thematic scope of the review concerned the situation of designer drugs in Poland.

\section{RESULTS}

\section{Definition of designer drugs}

The English-language scientific literature provides many synonyms for dopalacze" e.g. designer drugs, research chemicals, new psychoactive substances, legal highs. The term 'designer drugs' is used particularly in relation to psychostimulants and doping agents (designer steroids) (5). This review, however, concerns the situation in Poland, where 'designer drugs' are considered 'new drugs' (according to the latest GIS reports and amendment to the Act on counteracting drug addiction of 2018). These are products that contain psychoactive substances which affect the central nervous system (CNS), and can cause health damage similar to that caused by the use of classic drugs. New drugs include New Psychoactive Substances (NPSs) and substitutes (6). They are sold as products with a different purpose, such as stove kindling, electromagnetic radiation absorbents, or fragrance sachets. NPSs are usually smoked like marijuana, taken orally or nasally (7).

\section{NEW PSYCHOACTIVE SUBSTANCES AND SUBSTITUTES - CURRENT LEGAL STATUS}

New psychoactive substances are meant to produce a similar effect to that of cannabis, heroin or amphetamine (8). On August 21, 2018, the amendment to the Act on Counteracting Drug Addiction came into force. It contains the current definition of a New Psychoactive Substance (NPS) and enables us to approach designer drugs in the same manner as narcotic drugs in the light of the law. Possession of a significant amount of NPS for personal use may result in a fine, restriction of liberty and even imprisonment of up to 3 years. NPS trafficking is punishable by up to 12 years of prison (9).

A product containing a substance that acts on the CNS, which can be used for the same purpose as a narcotic drug, a psychotropic substance or a new psychoactive substance, is referred to as a 'substitute' (pol. środek zastępczy) in the Polish law. Until the composition of such drug is determined, that is until the chemical structure of the substances it contains is known (which allows the predicted effect of a substance to be determined with high probability), a financial penalty (administrative liability) may be incurred for its manufacture or introducing it to the market. The amount of the penalty depends on the requisitioned amount of the substitute. Possession of a substitute is punishable by criminal liability only
(SWPS). Wyszukiwano słowa kluczowe: „designer drugs”, „party pills”, „street drugs”, ,research chemicals”, „,new psychoactive substances”. Przeglądem niesystematycznym objęto literaturę opublikowaną w latach 2015-2019 w języku polskim i angielskim. Zakres tematyczny przeglądu dotyczył sytuacji dopalaczy na terenie Polski.

\section{WYNIKI}

\section{Definicja dopalaczy}

W anglojęzycznej literaturze naukowej można spotkać wiele synonimów „dopalaczy”, na przykład: designer drugs, research chemicals, new psychoactive substances, legal highs. Określenie designer drugs używane jest na świecie szczególnie w odniesieniu do substancji psychostymulujących, a także środków dopingujących (designer steroids) (5). Niniejszy przegląd dotyczy jednak sytuacji w Polsce, gdzie (nawiązując do najnowszych raportów GISu i nowelizacji ustawy o przeciwdziałaniu narkomanii, która miała miejsce w roku 2018) „dopalacze” uznawane są za „nowe narkotyki”. Są to produkty, w składzie których znajdują się substancje psychoaktywne oddziałujące na ośrodkowy układ nerwowy, mogące wywołać szkody zdrowotne podobne do tych, które są skutkiem stosowania klasycznych narkotyków. W skład nowych narkotyków wchodzą Nowe Substancje Psychoaktywne (NSP) oraz środki zastępcze (6). Są one sprzedawane jako produkty o innym przeznaczeniu, takie jak rozpałki do pieca, absorbery promieniowania elektromagnetycznego, czy saszetki zapachowe. Dopalacze są zazwyczaj palone w sposób podobny do marihuany, przyjmowane doustnie lub donosowo (7).

\section{NOWE SUBSTANCJE PSYCHOAKTYWNE I ŚRODKI ZASTĘPCZE - OBECNY STAN PRAWNY}

Nowe substancje psychoaktywne mają na celu odwzorowanie efektu oddziaływania na organizm substancji takich jak marihuana, heroina czy amfetamina (8). Dnia 21 sierpnia 2018 roku weszła w życie nowelizacja ustawy o przeciwdziałaniu narkomanii (u.p.n.). Zawarta jest w niej obowiązująca definicja Nowej Substancji Psychoaktywnej (NSP), umożliwiająca traktowanie $\mathrm{w}$ aspekcie prawnym dopalaczy na równi z narkotykami. Oznacza to, że posiadanie znacznej ilości NSP na własny użytek grozi karą grzywny, ograniczenia wolności, a nawet karą pozbawienia wolności do lat 3. Za handel NSP grozi do 12 lat więzienia (9).

Produkt zawierający substancję działającą na ośrodkowy układ nerwowy, który może być użyty w takich samych celach jak środek odurzający, substancja psychotropowa lub nowa substancja psychoaktywna, jest w polskim prawie określany jako „środek 
after its active substance has been isolated and added to the NPS registry $(9,10)$.

The introduction of the so-called generic law, so far in force in other European countries such as Germany and the United Kingdom is an important issue. It allows to outlaw in advance any substance belonging to one of the 4 NPS groups included in the ministerial regulation. The legislator provides a precise definition of substance groups, so that controlled are not only salts, esters or isomers of a specific substance, but also structurally related compounds differing from the original substance only by a substituent located at the ring $(9,11)$.

Thanks to the amendment to the Act on Counteracting Drug Addiction, the process of entering new substances into the list of prohibited substances should proceed in a considerably faster manner. Up until now, the entry into force of such a list required an amendment to the Act - now such lists will be attached to the Regulation of the Minister of Health, in order to speed up the prohibition process $(9,10)$.

The ordinance of the Minister of Health of August 17th, 2018 contains all previously controlled psychotropic substances and narcotics, four groups of generic NPS (I - 2-phenylethylamine derivatives, II - cathinone derivatives, III - synthetic cannabinoids, IV - fentanyl derivatives) as well as new psychoactive substances included in previous ordinances $(11,12)$.

\section{CLASSIFICATION OF NPSS ACCORDING TO THEIR EFFECT}

\section{Stimulating substances}

Stimulants cause psychomotor agitation, willingness to act and often elevated mood (13). The most often identified stimulating NPSs are derivatives of cathinone, a substance naturally occurring in a plant called Catha edulis (pol. czuwaliczka jadalna comes from the plant's wakefulness-maintaining properties). The intoxication is quite short due to the rapid metabolism of the substance (14). Side effects are similar to those observed after taking amphetamine, with dominating psychomotor agitation and tachycardia with hypertension. Using cathinones predisposes one to aggressive behavior and increases the risk of a heart attack (15).

One of the most well-known cathinones is mephedrone (4-methylmethcathinone), a stimulating and 'empathogenic' substance, i.e. increasing 'openness' in interpersonal relations. Until recently, mephedrone has been the most popular synthetic cathinone in Europe; in the USA it was methylone and 3,4-Methylenedioxypyrovalerone - MDPV (16). In 2017-2018 the most common cathinone (and the most common NPS in general) found in designer drugs was 4-CEC (6). A media sensation, zastępczy". Dopóki skład takiego środka nie zostanie ustalony, czyli do momentu poznania struktury chemicznej zawartych w nim substancji (co pozwala $z$ dużym prawdopodobieństwem określić przewidywane działanie substancji), za jego wytwarzanie bądź wprowadzanie do obrotu grozi kara finansowa (odpowiedzialność administracyjna). Jej wysokość zależy od ilości zarekwirowanego środka zastępczego. Dopiero po wyizolowaniu ze środka zastępczego substancji, której nazwa zostanie wpisana do wykazu NSP zawartego w ministerialnym rozporządzeniu, za jej posiadanie będzie grozić odpowiedzialność karna $(9,10)$.

Bardzo istotną kwestią jest także wprowadzenie tzw. prawa generycznego, obowiązującego do tej pory w innych krajach europejskich - takich, jak Niemcy i Wielka Brytania. Umożliwia ono delegalizację a priori substancji zaliczającej się do jednej z 4 grup NSP zawartych $\mathrm{w}$ rozporządzeniu ministerialnym. Ustawodawca ustala precyzyją definicję rodzin substancji tak, by kontrolą nie zostały objęte jedynie sole, estry czy izomery konkretnej substancji, ale także związki strukturalnie różniące się od wyjściowej substancji jedynie podstawnikiem znajdującym się przy pierścieniu $(9,11)$.

Dzięki omawianej nowelizacji u.p.n., proces wpisywania nowych substancji na listę związków zakazanych powinien przebiegać znacznie szybciej. Do tej pory wejście w życie takiej listy wymagało nowelizacji ustawy - teraz takie wykazy będą załączane do rozporządzenia ministra zdrowia, co ma na celu przyspieszenie procesu delegalizacji $(9,10)$.

W rozporządzeniu Ministra Zdrowia z dnia 17 sierpnia 2018 znajdują się wszystkie dotychczas objęte kontrolą substancje psychotropowe i środki odurzające, jak również cztery grupy generyczne NSP (I - pochodne 2-fenyloetyloaminy, II - pochodne katynonu, III - syntetyczne kannabinoidy, IV - pochodne fentanylu) oraz nowe substancje psychoaktywne z wcześniejszych rozporządzeń $(11,12)$.

\section{PODZIAŁ NOWYCH NARKOTYKÓW POD WZGLĘDEM DZIAŁANIA}

\section{Substancje stymulujące}

Są to substancje powodujące pobudzenie psychoruchowe, chęć do działania, często także poprawiające nastrój (13).

Najczęściej identyfikowanymi NSP o działaniu stymulującym są pochodne katynonu, substancji występującej naturalnie w roślinie Catha edulis (polska nazwa czuwaliczka jadalna wywodzi się od efektu działania tej rośliny - podtrzymywania stanu czuwania). Stan odurzenia trwa dość krótko ze względu na szybki metabolizm substancji (14). Działania niepożądane są podobne do tych obserwowanych po zażyciu amfetaminy, z dominacją pobudzenia psychoruchowe- 
$\alpha$-pyrrolidinopentiophenone ( $\alpha$-PVP), known as 'flakka' or 'zombie drug' (due to increased paranoid delusions and psychomotor agitation; a case of cannibalism following its use was reported as well) has experienced a drastic downfall in popularity, because its production in China was ceased and the substance was banned in many countries around the world (17).

\section{Psychodepressive substances}

They are compounds which inhibit CNS activity. The NPSs in this group include new benzodiazepines that have not been introduced into the pharmaceutical market or have been withdrawn from it, as well as synthetic opioids $(13,18)$. Synthetic opioids and new benzodiazepines are currently gaining more and more popularity. Their strong addictive and toxic potential as well as the difficulty of detecting them with routine tests based on biological samples raise concerns (19).

Both groups of compounds are sometimes referred to as 'post-partying substances', as their sedative effect is used, among others, to manage anxiety caused by overdose of psychostimulants, to reduce withdrawal symptoms, or to alleviate other side effects associated with their consumption, such as no longer desired psychomotor agitation that causes restlessness (20).

Simultaneous ingestion of a stimulant and an opioid is referred to as a 'speedball'. Many fatalities have been caused by their synergistic effect, as low doses of opioids may act as stimulants for the CNS (21). The risk of poisoning increases when several psychodepressive substances are combined (e.g. benzodiazepines with alcohol) or when intravenous injection, which provides the highest bioavailability, is the preferred route of administration (22).

The use of opioids with the strongest receptor affinity - fentanyl analogs - carries the highest risk of overdose. This group includes furanylfentanyl, butyrylfentanyl and acetylfentanyl; the most frequently confiscated in 2011-2016 in the USA was their parent compound - fentanyl. Carfentanil is one of the most potent opioids - its receptor affinity is more than a hundred times higher than fentanyl's. It occurs as a heroin contaminant, among other forms (23). Furanylfentanyl, cyclopropylfentanyl, U-47700 are appear on the Polish market under the following names: Gumiś, Talisman (GT, Green), China Breath. These substances have been gaining popularity in recent years (24).

The aforementioned U-47700 is also classified as an opioid. It shows high addictive potential; evoking severe, but short-lived euphoria U-47700 causes a strong desire to take the next dose, creates a high risk of overdose (25). go oraz tachykardii z hipertensją. Przyjmowanie katynonów predysponuje do przejawiania zachowań agresywnych, zwiększa także ryzyko wystąpienia zawału serca (15).

Jednym $\mathrm{z}$ najbardziej znanych katynonów jest mefedron (4-metylometkatynon), substancja stymulująca i „empatogenna”, tj. zwiększająca „otwartość” w stosunku do innych osób. Był to do niedawna najpopularniejszy syntetyczny katynon w Europie (w USA był to metylon i 3,4-Metylenodioksypirowaleron-MDPV) (16). W latach 2017-2018 najczęstszym katynonem (i najczęstszą NSP w ogóle) spotykanym w składzie dopalaczy był 4-CEC (6). Silnie nagłośniony przez media $\alpha$-pirolidynopentiofenon ( $\alpha$-PVP), znany jako ,flakka" lub ,narkotyk zombie" (ze względu powodowane nasilone urojenia paranoidalne i pobudzenie psychomotoryczne; doniesiono również o przypadku kanibalizmu po zażyciu tej substancji) znacznie stracił na rzeczywistej popularności, ze względu na zablokowanie jego produkcji w Chinach i zdelegalizowanie w wielu krajach na świecie (17).

\section{Substancje psychodepresyjne}

Są to związki hamujące aktywność OUN. Do NSP $\mathrm{w}$ tej grupie zaliczane są nowe benzodiazepiny, które nie zostały wprowadzone na rynek farmaceutyczny albo zostały z niego wycofane, a także opioidy syntetyczne $(13,18)$. Syntetyczne opioidy i nowe benzodiazepiny zyskują obecnie coraz większą popularność. Niepokój budzi ich silny potencjał uzależniający i toksyczny oraz trudności w ich wykrywaniu za pomocą rutynowych testów bazujących na materiale biologicznym (19).

Obydwie grupy związków bywają określane mianem „substancji poimprezowych” (z ang. post-partying substances), gdyż sedacja po ich zażyciu wykorzystywana jest $\mathrm{m}$. in. do opanowania lęku po przedawkowaniu substancji psychostymulujących, redukcji objawów abstynencyjnych lub łagodzenia innych skutków ubocznych związanych z ich zażyciem, takich jak niepożądane już pobudzenie psychoruchowe uniemożliwiające wypoczynek (20).

Jednoczesne przyjęcie substancji stymulującej i opioidu określane jest jako , speedball”. Odnotowano wiele przypadków śmiertelnych spowodowanych synergizmem tych klas związków, gdyż niskie dawki opioidów mogą działać stymulująco na OUN (21). Ryzyko zatrucia zwiększa się przy łączeniu kilku substancji psychodepresyjnych (np. benzodiazepin z alkoholem) oraz przy preferowaniu iniekcji dożylnej jako drogi podania (najwyższa biodostępność) (22). 
The depressive effect of opioids on the respiratory center may in case of overdose, cause death in the mechanism of sudden respiratory arrest, especially in case of using the strongest opioids such as fentanyl (22).

A person under the influence of opioids, as well as other CNS-inhibitors, is usually entangled, drowsy and presents with the symptom particularly characteristic of opioid intoxication - pinpoint pupils (24). Diagnosis of poisoning with psychodepressants and distinguishing between symptoms of opioid and benzodiazepine poisoning is crucial, because both cases can be treated with an antidote. Administration of naloxone reverses all symptoms of opioid poisoning, including respiratory depression (26).

Flunitrazepam is an excellent example of a benzodiazepine which as a substance with therapeutic use became a popular drug of abuse. It is used for recreational purposes, or administered to third parties as a 'rape pill'. Currently, only in some countries is flunitrazepam authorized as a hypnotic drug (27). Etizolam, on the other hand, is an example of a designer benzodiazepine not registered as a therapeutic agent (28). When we consider percentages in Poland, there has been a fourfold increase in benzodiazepine identification in 2018 compared to the previous year (6).

\section{Psychodysleptic substances}

The influence of psychodysleptics on the CNS affects cognitive and emotional functioning (13). Many of them exert their action through serotonin receptors. These are the so-called classical hallucinogens (psychedelics) -5HT2A-R agonists: phenylethylamine (2C-X and NBOM-e compounds), lysergamides, tryptamines, piperazines (29). Psychedelics often appear on the market in the form of blotters - pieces of paper/cardboard impregnated with a psychoactive substance. Psychedelics are also taken by mouth or injected (30). Another class of hallucinogenic substances are dissociatives - NMDA-R agonists that cause depersonalization and derealization. These include arylcyclohexamines and morphinates. The third group are deliriants, i.e. cholinolytic compounds - mACh-R antagonists that cause delirium. CB1-R agonists (synthetic cannabinoids), D2R agonists, GABA-A-R agonists and other groups of compounds also constitute the psychodysleptic family (29).

The most dangerous psychodysleptics are NPSs from the NBOM-e family. For example, ingesting 1.5 milligrams of LSD can cause unpleasant sensations without serious intoxication while the same dose of a NBOM-e can be lethal. Typical symptoms of poisoning with these substances are cardiovascular symptoms (chest pain, palpitations, hypertension),
Używanie opioidów o najsilniejszym powinowactwie receptorowym - analogów fentanylu, niesie ze sobą największe ryzyko przedawkowania. Do tej grupy zaliczamy $\mathrm{m}$. in. furanylofentanyl, butyrylofentanyl i acetylofentanyl, przy czym najczęściej konfiskowanym w latach 2011-2016 w USA był związek wyjściowy - fentanyl. Karfentanyl jest jednym z najsilniejszych znanych opioidów - wykazuje ponad stukrotnie większe powinowactwo receptorowe od fentanylu. Spotykany jest $\mathrm{m}$. in. jako zanieczyszczenie heroiny (23). Furanylfentanyl, cyklopropylofentanyl, U-47700 obecne są na polskim rynku $\mathrm{m}$. in. w produktach: Gumiś, Talizman (GT, Zielony), China Breath. Substancje te zyskiwały w ostatnich latach na popularności (24).

Substancja o symbolu U-47700 także zaliczana jest do opioidów. Wykazuje ona wysoki potencjał uzależniający. Wywołując nasiloną, jednak krótkotrwałą euforię, powoduje silną chęć do wzięcia następnej dawki, co wiąże się z ryzykiem przedawkowania (25).

Działanie depresyjne opioidów na ośrodek oddechowy w pniu mózgu może, w przypadku przedawkowania, spowodować zgon w mechanizmie nagłego zatrzymania oddechu, szczególnie przy stosowaniu najsilniejszych opioidów, jakimi są fentanyle (22).

Osoba pod wpływem opioidów, jak również innych substancji o działaniu hamującym aktywność OUN, jest zwykle splątana, podsypiająca, a objawem szczególnie charakterystycznym dla użycia opioidów są szpilkowate źrenice (24). Rozpoznanie zatrucia substancjami psychodepresyjnymi i różnicowanie objawów zatrucia opioidami i benzodiazepinami jest bardzo istotne, gdyż w obu przypadkach istnieje możliwość podania odtrutki. Podanie naloksonu odwraca wszystkie objawy zatrucia opioidami, łącznie z depresją oddechową (26).

Doskonałym przykładem benzodiazepiny, która z substancji o zastosowaniu leczniczym stała się dość popularnym środkiem odurzającym, jest flunitrazepam, stosowany w celach rekreacyjnych albo podawany osobom trzecim jako ,pigułka gwałtu”. Obecnie tylko w niektórych krajach flunitrazepam jest dopuszczony do obrotu jako lek o działaniu nasennym (27). Przykładem projektowanej benzodiazepiny niezarejstrowanej nigdy jako środek leczniczy jest etizolam (28). W odniesieniu do procentowej identyfikacji nowych narkotyków, nastąpił czterokrotny wzrost identyfikacji benzodiazepin na terenie Polski w roku 2018, w stosunku do roku 2017 (6).

\section{Substancje psychodysleptyczne}

Oddziaływanie substancji psychodysleptycznych na OUN wpływa na funkcjonowanie poznawcze i emocjonalne (13). Wiele z nich działa poprzez receptory serotoninowe. Sa to tak zwane halucynogeny klasyczne (psychodeliki) - agoniści 5HT2A-R: 
bleeding, neurological disorders (agitation, aggression, convulsions), mental disorders (hallucinations, psychoses) (13).

\section{Synthetic cannabinoids}

Cannabinoids are mixed-action psychoactive substances that, depending on the dose used, may have a stimulatory, depressive or psychedelic effect, as well as any combination of these. On the market the most common are plant products mixed with NPSs - synthetic cannabinoids, which act similarly to $\Delta 9$ tetrahydrocannabinol (THC), a natural psychoactive compound found in marijuana (13).

Synthetic cannabinoids usually do not have common names; instead they are given appropriate letter-digit codes based on the name of the laboratory where they were first obtained, such as: JWH J.W Hoffmann Laboratory, CP - Pfitzer Laboratory. Examples include cyclohexyl phenol analogs (CP 47, 59, 497, 540), naphtholindoles (JWH-018, 073), naphtolpyrroles or phenylcylindoles (JWH 259) (JWH 259). These compounds differ in the structure from the THC found in marijuana but interact with the same receptors. Synthetic cannabinoids are more dangerous than marijuana due to their stronger receptor affinity and numerous side effects (31). In poisoning with synthetic cannabinoids, like in psychostimulant poisoning, psychomotor agitation is the dominating component, usually much stronger than that observed after marijuana. Hallucinations, hypertension, tachycardia, and sometimes convulsions all occur as well. The use of synthetic cannabinoids may result in acute coronary syndrome, stroke and death $(31,32$, $33)$.

It should be emphasized that the compounds in question are often sold in blends, mixed also with substances belonging to completely different drug groups, e.g. with tramadol, caffeine or nicotine (34). In addition, the varied content of synthetic cannabinoids in herbal mixtures further increases the risk of serious side effects, including fatal overdose (31). Taking this into consideration it is clear that synthetic cannabinoids constitute an extremely dangerous drug group, especially in hands of a person who 'would like to try marijuana for the first time' and is not aware of the type of substance being taken and the risks associated with it.

\section{EPIDEMIOLOGICAL SITUATION OF DESIGNER DRUGS IN POLAND}

In 2017, results of research conducted in April 2013 - June 2015 were summarized and published as a book, providing knowledge on the perception and use of NPS in Poland, implemented by SWPS and KBPN as part fenyloetyloaminy (związki szeregu 2C-X i NBOM-e), lizergamidy, tryptaminy, piperazyny (29). Często występującą postacią rynkową psychodelików są kawałki papieru/tekturki nasączane odpowiednią substancją (kartoniki). Substancje te bywają również przyjmowane doustnie lub w iniekcjach (30). Kolejną klasą substancji halucynogennych są dysocjanty - agoniści NMDA-R, powodujące depersonalizację i derealizację. Należą do nich arylcykloheksaminy i morfinany. Trzecią grupę stanowią delirianty, czyli związki cholinolityczne - antagoniści mACh-R, wywołujące zespół majaczeniowy. Do związków psychodysleptycznych zaliczani są także agoniści CB1-R (kannabinoidy syntetyczne), agoniści D2R, GABA-A-R agoniści i inne grupy związków (29).

Do najbardziej niebezpiecznych związków psychodysleptycznych należą NSP z rodziny NBOMe. Przykładowo, przyjęcie dawki 1,5mg LSD może wywołać nieprzyjemne doznania nie prowadząc przy tym do poważnego zatrucia, podczas gdy ta sama dawka substancji z grupy NBOMe może okazać się śmiertelna. Typowe objawy zatrucia tymi substancjami to $\mathrm{m}$. in. objawy ze strony układu sercowo-naczyniowego (ból w klatce piersiowej, kołatanie serca, nadciśnienie), krwawienia, zaburzenia neurologiczne (pobudzenie, agresja, drgawki), zaburzenia psychiczne (halucynacje, psychozy) (13).

\section{Syntetyczne kannabinoidy}

Kannabinoidy są substancjami psychoaktywnymi o działaniu mieszanym, które w zależności od przyjętej dawki mogą wykazywać działanie stymulacyjne, depresyjne lub psychodeliczne, a także kombinację tych działań. Najczęściej na rynku występują produkty roślinne zmieszane z NSP - syntetycznymi kannabinoidami, działającymi podobnie do $\Delta$ 9-tetrahydrokannabinolu (THC), naturalnego związku psychoaktywnego występującego w marihuanie (13).

Syntetyczne kannabinoidy najczęściej nie posiadają nazw zwyczajowych, natomiast nadaje się im odpowiednie kody literowo-cyfrowe, pochodzące od nazwy laboratorium, gdzie zostały otrzymane, przykładowo: JWH - Laboratorium J.W Hoffmana, CP - Laboratorium Pfitzera. Przykładami sąanalogi cykloheksylofenolu (CP 47, 59, 497, 540), naftoloindole (JWH-018, 073), naftolopirole czy fenylocetyloindole (JWH 259). Związki te różnią się budową od THC występującego w konopiach, ale działają na te same receptory w organizmie. Syntetyczne kannabinoidy są zdecydowanie bardziej niebezpieczne niż marihuana, ze względu na silniejsze powinowactwo receptorowe i więcej objawów niepożądanych (31). W zatruciach kannabinoidami syntetycznymi, podobnie jak w zatruciach psychostymulantami, dominuje pobudzenie psychoruchowe. Jest ono zwykle znacznie silniejsze, niż te obserwowa- 
of the international project I-TREND (Internet tools for research in Europe on new drugs). The online survey was filled by 1385 participants, $88 \%$ of whom were young men and women under 25 years old. Based on these data, the study's authors conclude that in Poland the users of new drugs are mainly adolescents and young adults.

The most frequently reported substance turned out to be mephedrone (despite having been outlawed in 2011), ingested by $34.1 \%$ of respondents who used any designer drug, at any time in their lives. Based on the responses, mephedrone turned out to be the fifth most popular substance used at least once in a lifetime, right behind alcohol $(97,8 \%)$, tobacco $(94,9 \%)$ marijuana/ hashish $(93,1 \%)$, and amphetamine/methamphetamine $(57,1 \%)$. The average age of the first contact with new drugs is 17 years. Almost all respondents had previous experience of using alcohol, tobacco and drugs. Test subjects were usually residents of large cities, who had relatively low wages and were dependent on their parents, were studying, or just starting their careers.

Almost half of the respondents confessed to experiencing negative side effects. The most harmful were: pentedrone, $\alpha$-PVP and ethcathinone. The most common side effects were: aggression, breathing difficulties and shortness of breath (reported by $1 / 4$ of the respondents); muscle aches, muscle cramps, trismus and overheating (noticed by $1 / 4$ of the respondents) (35).

Based on a study conducted by CBOS and KBPN, in 2016 68\% of the participants have heard of 'designer drugs' (knowledge of the term), and in 2018- 64\% of the participants. In $2018,1.3 \%$ (1.7\% in 2016) of the respondents bought designer drugs in brick and mortar stores. When it came to online stores, $1,4 \%(1,1 \%$ in 2016) of students used Polish stores and 1,4\% (1,1\% in 2016) used foreign stores. A similar percentage of respondents used hidden internet exchanges, the so-called cripto markets $-1,8 \% 255(1,1 \%$ in 2016$)$. A different way of purchase was chosen by 3,5\% (2,3\% in 2016) respondents - from dealers or friends (36).

In 2015, a record number of medical interventions was recorded, as many as 7,283 due to designer drugs, which was a threefold increase compared with 2014. In the years 2016-2018 the number of poisonings dropped to around 4,300 cases, which is still a very large number (36).

Table I presents a summary of the number of suspicions of poisoning with designer drugs by voivodeship, per 100,000 residents in 2015-2018. Łódź and Silesian voivodeships have the highest number of poisoning reports, several times higher than those observed in other voivodeships.

In 2015-2017 there is a visible downward trend in the nationwide number of poisonings with designer drugs $(6,37)$. ne po marihuanie. Występują także halucynacje, hipertensja, tachykardia, niekiedy drgawki. W wyniku ich zażycia może dojść do ostrego zespołu wieńcowego, udaru mózgu i zgonu $(31,32,33)$.

Należy podkreślić, że omawiane związki często są sprzedawane $w$ mieszankach, także z substancjami należącymi do zupełnie innych grup, np. $\mathrm{z}$ tramadolem, kofeiną lub nikotyną (34). Ponadto, zróżnicowana zawartość syntetycznych kannabinioidów w mieszankach ziołowych dodatkowo zwiększa ryzyko wystąpienia poważnych działań ubocznych, w tym śmiertelnego przedawkowania (31).

Jak wynika z powyższego, syntetyczne kannabinoidy stanowią wyjątkowo niebezpieczną grupę związków, szczególnie gdy trafiają w posiadanie osoby nie mającej świadomości co do rodzaju przyjmowanej substancji i związanych z nią zagrożeń, która „pierwszy raz chciałaby spróbować marihuany".

\section{SYTUACJA EPIDEMIOLOGICZNA DOPALACZY W POLSCE}

W roku 2017 w postaci publikacji książkowej zostały podsumowane wyniki badań z okresu kwiecień 2013 - czerwiec 2015, dostarczających wiedzy na temat postrzegania i używania NSP na terenie Polski, realizowanych przez SWPS i KBPN w ramach międzynarodowego projektu: I-TREND (Internet tools for research in Europe on new drugs). W ankiecie on-line wzięło udział 1385 osób, w której 88\% stanowili młodzi mężczyźni i kobiety poniżej 25 roku życia. Opierając się na tych danych, autorzy badania wnioskują, iż w Polsce użytkownikami nowych narkotyków są głównie młodzież i młodzi dorośli.

Najpopularniejszą substancją spośród podawanych przez badanych okazał się mefedron (pomimo zdelegalizowania w roku 2011), którego zażycie podawało 34,1\% respondentów zażywających jakikolwiek dopalacz, kiedykolwiek w życiu. Mefedron, bazując na odpowiedziach respondentów, okazał się piątą najpopularniejszą używką stosowaną chociaż raz w życiu, zaraz za alkoholem (97,8\% respondentów), tytoniem $(94,9 \%)$, marihuaną/haszyszem $(93,1 \%)$ i amfetaminą/ metamfetaminą $(57,1 \%)$. Wiek pierwszego kontaktu z nowymi narkotykami to średnio około 17 lat. Prawie wszyscy respondenci mieli wcześniejsze doświadczenie używania alkoholu, tytoniu i narkotyków. Badane osoby to zazwyczaj mieszkańcy dużych miast, którzy mają stosunkowo niskie zarobki i są na utrzymaniu rodziców, uczą się, studiują lub dopiero rozpoczynają karierę zawodową.

Do odczuwania negatywnych efektów ubocznych przyznała się prawie połowa respondentów. Najbardziej szkodliwe okazały się: pentedron, alfa-PVP i etkatynon. Najczęściej odczuwanymi skutkami były: 
Table I. IMED rates (intoxication / suspected intoxication with NPSs and substitutes) per 100 thousand residents of respective Polish voivodeships in 2015-2018.

Tabela I. Wskaźniki IMED (zatruć/podejrzeń zatruć NSP i środkami zastępczymi) na 100 tys. Mieszkańców poszczególnych województw Polski w latach 2015-2018

\begin{tabular}{|c|c|c|c|c|}
\hline VOIVODESHIP & 2015 & 2016 & 2017 & 2018 \\
\hline Lower Silesia & 9,62 & 3,58 & 3,27 & 4,86 \\
\hline Kujawy-Pomerania & 22,48 & 9,25 & 10,89 & 12,59 \\
\hline Lublin & 9,12 & 8,83 & 8,87 & 12,91 \\
\hline Lubusz & 40,38 & 13,65 & 6,29 & 15,46 \\
\hline Lódi் & 59,62 & 57,74 & 38,54 & 44,28 \\
\hline Lesser Poland & 4,16 & 3,32 & 7,7 & 4,41 \\
\hline Masovia & 8,07 & 3,57 & 4,96 & 5,63 \\
\hline Opole & 2,99 & 0,6 & 1,21 & 1,61 \\
\hline Subcarpathian & 6,62 & 1,26 & 0,93 & 2,44 \\
\hline Podlaskie & 11,91 & 4,03 & 4,55 & 4,39 \\
\hline Pomerania & 16,15 & 11,3 & 7,5 & 4,74 \\
\hline Silesia & 40,34 & 21,41 & 27,72 & 24,51 \\
\hline Świętokrzyskie & 10,44 & 11,21 & 8,48 & 5,05 \\
\hline Warmia-Mazuria & 21,33 & 6,73 & 8,22 & 6,56 \\
\hline Greater Poland & 20,1 & 9,12 & 10,76 & 8,3 \\
\hline West Pomerania & 10,84 & 3,5 & 2,92 & 4,99 \\
\hline national average & 18,92 & 11,19 & 11 & 11,08 \\
\hline
\end{tabular}

For several years in Poland, cathinones and synthetic cannabinoids have been the most popular of identified new drugs. In 2018, these two groups of substances together accounted for nearly $88 \%$ of new drug identifications, compared with as much as $93 \%$ in the previous year. The table below shows the share of the predominant substances on the Polish designer drug market in 20172018. The dominant group consists of cathinones (4-CEC, N-prophylpentedrone, HEX-EN, PV8, NEP, 3-CMC, 4-CMC, NEMNP, N-ethylpentylone, $\alpha$-PHiP, 4-Cl- $\alpha$ PVP) and the rest are synthetic cannabinoids (5F-ADB, MDMB-CHIMICA, FUB-AMB) (6).

When we compare the data from both tables, it can be seen that despite a much smaller number of the most popular new drugs in Poland (representing more than half of the market share of designer drugs in Poland) identified in 2018 (929 identifications) compared to 2017 (1701 identifications), the national average of poisonings per 100,000 inhabitants increased in 2018 to 11.08 , compared with 11.00 in the previous year.

This may result from the emergence of new, more dangerous drugs. Results of laboratory analyses show that substances of various purity are sold at similar prices agresja i problemy z oddychaniem oraz duszności (zauważane przez około 1/4 respondentów); bóle mięśni, skurcze, szczękościsk oraz przegrzewanie organizmu (zauważane przez około 1/6 respondentów) (35).

$\mathrm{Na}$ podstawie badania przeprowadzonego przez CBOS i KBPN, w 2016 roku o „,dopalaczach” słyszało (znajomość terminu) 68\% ankietowanych, a w 2018 roku $-64 \%$. W roku 2018, 1,3\% (1,7\% w 2016) badanych kupowało dopalacze w sklepach stacjonarnych. $\mathrm{Z}$ polskiego sklepu internetowego korzystało 1,4\% $(1,1 \%$ w 2016$)$ uczniów, a ze sklepu zagranicznego - 1,4\% (1,1\% w 2016). Podobny odsetek badanych korzystał z ukrytych giełd internetowych, tzw. kryptomarketów - 1,8\% $255(1,1 \%$ w 2016). W inny sposób kupowało je 3,5\% (2,3\% w 2016) ankietowanych - od dilerów czy znajomych (36).

W 2015 roku odnotowano rekordową liczbę interwencji medycznych, bo aż $7283 \mathrm{z}$ powodu dopalaczy, co stanowiło trzykrotny wzrost w stosunku do roku 2014. W latach 2016-2018 liczba zatruć spadła do około 4300 przypadków, co nie zmienia faktu, że nadal jest to bardzo duża liczba (36).

Tabela I prezentuje zestawienie danych na temat liczby podejrzeń zatruć dopalaczami z podziałem na województwa, w przeliczeniu na 100 tyś. mieszkańców w latach 2015-2018. Najwięcej zatruć odnotowuje się w województwie łódzkim i śląskim, przy czym są to wartości aż kilkakrotnie przekraczające te, obserwowane na terenie pozostałych województw. W latach 2015-2017 zauważalny jest trend spadkowy co do liczby zatruć dopalaczami w skali kraju $(6,37)$.

W Polsce od kilku lat największą popularnością wśród identyfikowanych grup nowych narkotyków cieszą się katynony i syntetyczne kanabinoidy. W 2018 r. te dwie grupy substancji łącznie stanowiły blisko $88 \%$ oznaczeń nowych narkotyków, w porównaniu do aż 93\% w roku poprzednim. Poniżej w formie tabeli został przedstawiony udział przeważających substancji na polskim rynku dopalaczy w latach 20172018. Dominującą grupę stanowią katynony (4-CEC, N-propylopentedron, HEX-EN, PV8, NEP, 3-CMC, 4-CMC, NEMNP, N-etylopentylon, $\alpha$-PHiP, 4-Cl- $\alpha$ -PVP), a resztę syntetyczne kannabinoidy (5F-ADB, MDMB-CHIMICA, FUB-AMB) (6).

Zestawiając dane z obydwu tabel można spostrzec, że pomimo zidentyfikowania znacznie mniejszej liczby najpopularniejszych nowych narkotyków na terenie Polski (stanowiących ponad połowę udziału na rynku dopalaczy w Polsce) w roku 2018 (929 identyfikacji) w porównaniu do roku 2017 (1701 identyfikacji), średnia krajowa odnotowywanych zatruć na 100 tys. mieszkańców wzrosła w roku 2018 do 11,08 , w porównaniu do 11,00 w roku 2017. 
on the drug market. As a result, even an experienced user with knowledge of the purchased substance may be surprised by the strength of its action (35).

\section{SUMMARY}

People who have isolated or created substances, which today are the mother compounds for thousands of new psychoactive substances, had a noble aim - to enable the treatment of various diseases. This aim has been and will be achieved many times again, but in many cases the identification of new chemical compounds has contributed to the creation and spreading of substances called designer drugs, due to insufficient regulation of the legal status of these substances. The coming years will show to what extent the recently introduced changes to the Act on Counteracting Drug Addiction will have reduced the amount of designer drug poisonings. Reports from 2017-2018 show that despite a significant decrease in the number of identified NPSs and substitutes, the number of poisonings remains largely the same. This may result from the emergence of more dangerous derivatives of banned substances on the market and/or from an increased amount of impurities found in new ones.

For this reason, it is necessary to launch further educational programs, raising awareness about designer drugs among adolescents and young adults - groups especially interested in consuming designer drugs.

\section{REFERENCES}

1. Wohlfarth A, Weinmann W. Bioanalysis of new designer drugs. Bioanalysis 2010; 2: 965-979

2. Wilczyńska K, Simonienko K, Kwiatkowski M, Waszkiewicz N, Wygnał N. Psychoza po dopalaczach - postępowanie dyżurowe.PsychiatrDypl 2017; 12: 9-15

3. Luciano RL, Perazella MA. Nephrotoxic effects of designer drugs: synthetic is not better! Nat Rev Nephrol 2014; 10: 314-324

4. Weaver MF, Hopper J A, Gunderson E W. Designer drugs 2015: assessment and management. Addict Sci Clin Pract 2015; 10: 8

5. Teale P, Scarth J, Hudson S. Impact of the emergence of designer drugs upon sports doping testing. Bioanalysis 2012; 4: 71-88

6. Nowe narkotyki w Polsce 2017-2018, raport Głównego Inspektora Sanitarnego https://gis.gov.pl/aktualnosci/ nowe-narkotyki-w-polsce-2017-2018-raport-glownego-inspektora-sanitarnego/ (01.08.2019)

7. Szajewski J. Dopalacze. Med Prakt 2010; 10: 110-112

8. Barczuk K. Nowe narkotyki w praktyce służb Państwowej Inspekcji Sanitarnej — ujęcie przekrojowe. W: Nowe narkotyki w Polsce. Tendencje, zagrożenia, procedury postępowania red.: E. Waluk. Główny Inspektorat Sanitarny, Warszawa 2016, 54-65

9. Ustawa z dnia 20 lipca 2018 r. o zmianie ustawy o przeciwdziałaniu narkomanii oraz ustawy o Państwowej Inspekcji SanitarnejDziennik Ustaw 2018, poz. 1490
Table II. Number and percentage distribution of the most popular new drugs (NPS and substitutes) identified by the Chief Sanitary Inspectorate in 2017-2018 in Poland.

Tabela II. Liczba i rozkład procentowy najpopularniejszych nowych narkotyków (NSP i środki za stępcze) zidentyfikowanych przez Główny Inspektorat Sanitarny w latach 2017-2018 na terenie Polski.

\begin{tabular}{|c|c|c|}
\hline$\overbrace{\text { SUBSTANCE }}^{\text {YEAR }}$ & 2017 & 2018 \\
\hline 4-CEC & $400(17,68 \%)$ & $203(14,35 \%)$ \\
\hline N-prophylpentedrone & $280(12,37 \%)$ & $99(7,00 \%)$ \\
\hline HEX-EN & $245(10,83 \%)$ & $168(11,87 \%)$ \\
\hline $5 F-A D B$ & $178(7,87 \%)$ & $152(10,84 \%)$ \\
\hline PV8 & $152(6,72 \%)$ & \\
\hline NEP & $129(5,70 \%)$ & $60(4,24 \%)$ \\
\hline MDMB-CHIMICA & $93(4,11 \%)$ & \\
\hline 3-CMC & $92(4,07 \%)$ & \\
\hline 4-CMC & $81(3,58 \%)$ & $42(2,97 \%)$ \\
\hline NEMNP & $51(2,25 \%)$ & \\
\hline N-ethylpentylone & & $76(5,37 \%)$ \\
\hline FUB-AMB & & $49(3,46 \%)$ \\
\hline$\alpha$-PHiP & & $42(2,97 \%)$ \\
\hline 4-Cl- $\alpha$-PVP & & $38(2,69 \%)$ \\
\hline together & $1701(75,18 \%)$ & $929(65,66 \%)$ \\
\hline
\end{tabular}

Może to być efektem pojawiania się nowych, groźniejszych narkotyków. Wyniki analiz laboratoryjnych pokazują, że na rynku narkotykowym w podobnych cenach sprzedawane są substancje o różnej czystości. W efekcie, nawet użytkownik posiadający wiedzę na temat zażywania zakupionej substancji może zostać zaskoczony mocą jej działania (35).

\section{PODSUMOWANIE}

Osobom, które wyizolowały bądź stworzyły substancje, będące dzisiaj związkami macierzystymi dla tysięcy nowych substancji psychoaktywnych, przyświecał szczytny cel - umożliwienie bądź pomoc w leczeniu różnych schorzeń. Cel ten wiele razy został lub zostanie osiągnięty, jednak w wielu przypadkach identyfikacja nowych związków chemicznych przyczyniła się do powstania i rozpowszechnienia substancji nazywanych potocznie dopalaczami (w Polsce), z czym miało związek niedostateczne uregulowanie statusu prawnego tych substancji. Najbliższe lata pokażą, w jakim stopniu ostatnio wprowadzone zmiany w ustawie o przeciwdziałaniu narkomanii wpłyną na ograniczenie liczby zatruć dopalaczami. Raporty z lat 2017-2018 pokazują, że pomimo znacz- 
10. Ustawa o tzw. dopalaczach wchodzi w życie https:// www.gov.pl/web/zdrowie/ustawa-o-tzw-dopalaczach-wchodzi-w-zycie (09.01.2019)

11. Nowe rozwiązania prawne dotyczące „dopalaczy” https://www.cinn.gov.pl/portal?id=1351805 (01.08.2019)

12. Rozporządzenie Ministra Zdrowia z dnia 17 sierpnia 2018 r. w sprawie wykazu substancji psychotropowych, środków odurzających oraz nowych substancji psychoaktywnych Dziennik Ustaw 2018, poz. 1591

13. Zuba D. Czym są nowe narkotyki z jakimi mamy do czynienia na rynku polskim w ostatnich latach? W: Nowe narkotyki w Polsce. Tendencje, zagrożenia, procedury postępowania red.: E. Waluk. Główny Inspektorat Sanitarny, Warszawa 2016, 14-36

14. Szukalski B, Błachut D, Bykas-Strękowska M. Dopalacze - nowe psychoaktywne preparaty objęte kontrolą (nowelizacja ustawy o przeciwdziałaniu narkomanii) Probl.Krym., 2009; 265: 19-32

15. Hoffman R, Al'Absi M. What use and neurobehavioral functions: suggestions for future studies J Ethnopharmacol 2010; 132: 554-563

16. Weinstein AM, Rosca P, Fattore L, London ED. Synthetic Cathinone and Cannabinoid Designer Drugs Pose a Major Risk for Public Health Front. Psychiatry 2017; 8: 156

17. Salani D, Albuja LD, Zdanowicz MM. The Explosion of a New Designer Drug, Flakka: Implications for Practice. J Addict Nurs 2018; 29: 255-259

18. Synthetic Opioid Overdose Data. https:/www.cdc.gov/ drugoverdose/data/fentanyl.html (10.01.2019)

19. Concheiro M, Chesser R, Pardi J, Cooper G. Postmortem Toxicology of New Synthetic Opioids Front. Pharmacol2018; 9: 1210

20. Schmitz A.: Benzodiazepine use, misuse, and abuse: A review Ment. Health Clin., 2016; 6: 120-126

21. Trujillo KA, Smith ML, Guaderrama MM. Powerful behavioral interactions between methamphetamine and morphine Pharmacol Biochem Behav 2011; 99: 451-458

22. Tas B, Day E. Pharmacology and physiological mechanisms of opioid overdose and reversal. W: Preventing opioid overdose deaths with take-home naloxone red.: J. Strang, R. McDonald. European Monitoring Centre for Drugs and Drug Addiction (EMCDDA), Luxembourg: Publications Office of the European Union 2016, 15-27

23. Prekupec MP, Mansky PA, Baumann MH. Misuse of Novel Synthetic Opioids: A Deadly New Trend. J AddictMed 2017; 11: 256-265

24. Wzrost liczby przypadków zatruć i śmierci z powodu użycia opioidów, zawartych w nowych narkotykach (tzw. ,dopalaczach") https://gis.gov.pl/aktualnosci/wzrost-liczby-przypadkow-zatruc-i- smierci-z-powodu-uzycia-opioidow-zawartych-w-nowych-narkotykach-tzw-dopalaczach/.

25. Elliott S P, Brandt S D, Smith C. The first reported fatality associated with the synthetic opioid 3,4-dichloro-N-[2-(dimethylamino)cyclohexyl]-N-methylbenzamide (U-47700) and implications for forensic analysis Drug Test Anal 2016; 8: 876-879

26. Boyer EW. Management of opioid analgesic overdose N Engl J Med 2012; 367: 146-155 nego spadku liczby identyfikowanych NSP i środków zastępczych, liczba zatruć utrzymuje się na tym samym poziomie. Może to wynikać z pojawiania się na rynku groźniejszych pochodnych zdelegalizowanych substancji i/lub ze wzrostu ilości dodawanych zanieczyszczeń do nowych narkotyków. $Z$ tego powodu niezbędne jest przeprowadzanie kolejnych akcji edukacyjnych, zwiększających świadomość na temat dopalaczy wśród młodzieży i młodych dorosłych - grup wiekowych szczególnie zainteresowanych używaniem dopalaczy.

27. Facing Addiction in America: The Surgeon General's Report on Alcohol, Drugs, and Health. Rohypnol ${ }^{\circledR}$ (Flunitrazepam) https://www.ncbi.nlm.nih.gov/books/ NBK424847/table/appd.t18/ (11.01.2019)

28. Manchester KR, Lomas EC, Waters L, Dempsey FC, Maskell PD. The emergence of new psychoactive substance (NPS) benzodiazepines: A review Drug Test Anal 2018; 10: 37-53

29. PSYCHEDELICS, DISSOCIATIVES AND DELIRIANTShttp://self.gutenberg.org/articles/Psychedelics,_dissociatives_and_deliriants?View=embed$\operatorname{ded} \% 27$ (12.01.2019)

30. Nichols DE. Psychedelics. Pharmacol Rev 2016; 68: 264-355

31. Castaneto MS, Gorelick DA., Desrosiers NA, Hartman RL, Pirard S, Huestis MA. Synthetic cannabinoids: epidemiology, pharmacodynamics, and clinical implications. Drug Alcohol Depend 2014; 144: 12-41

32. Cohen K, Weinstein AM. Synthetic and Non-synthetic Cannabinoid Drugs and Their Adverse Effects-A Review From Public Health Prospective Front. Public Health 2018; 6: 162

33. Synthetic Cannabinoids: An Overview for Healthcare Providers https://www.cdc.gov/nceh/hsb/chemicals/sc/ healthcare.html (12.01.2019)

34. Evren C, Bozkurt M. Synthetic cannabinoids: crisis of the decade Dusunen Adam 2013; 26: 1-11

35. Nowe substancje psychoaktywne - nowe ryzyka i wyzwania https://www.cinn.gov.pl/portal?id=15\&res $\mathrm{id}=1280468(01.08 .2019)$

36. Raport z badania pn. „Młodzież 2018” https://www. cinn.gov.pl/portal?id=1475772 (01.08.2019)

37. Dane statystyczne: Wykaz środków zastępczych, nowych substancji psychoaktywnych i innych substancji https://gis.gov.pl/bez-kategorii/dane-statystyczne/ (01.08.2019)

Received: 16.04.2019

Accepted for publication: 12.08.2019

Otrzymano: 16.04.2019 r.

Zaakceptowano do publikacji: 12.08.2019 r.

Address for correspondence:

Adres do korespondencji:

Emil Bartosz Rozenek

Students' Scientific Circle at the Department of Psychiatry

Medical University of Bialystok

16-070 Choroszcz, pl. Brodowicza 1

e-mail: e.rozenek@o2.pl 